UDC 94(477.83)«1945/1954»

DOI: 10.24919/2519-058x.7.131213

Vasyl ILNYTSKYI,

orcid.org/0000-0002-4969-052X

Ph D hab. (History), Associate Professor, Head of Department of Ukraine's History of Ivan Franko Drohobych State Pedagogical University

(Ukraine,Drohobych)vilnickiy@gmail.com Natalia KANTOR,
Senior Lecturer of Law, Sociology and Political Science Departament,
orcid.org/0000-0001-9533-0851
Ivan Franko Drohobych State Pedagogical University (Ukraine, Drohobych)
natali.kantor@gmail.com

\title{
REPRISALS OF THE SOVIET ADMINISTRATION AGAINST FAMILIES OF INSURGENTS IN KARPATSKYI KRAI OF THE OUN $\left(1945\right.$ - 1954) ${ }^{1}$
}

In the article on the basis of unknown and little-known documents the problem of use of families of nationalists in the combinations of Soviet law enforcement agencies is investigated for the first time. The basic directions of this policy of the repressive bodies are singled out. The author has proved that this line of activity of the special agents was an extremely important factor to play.

Key words: Karpatskyi Krai of the OUN, liberation movement, nationalists, families, repressive bodies.

Василь ІЛЬНИЦьКИЙ, доктор історичних наук, дочент, завідувач кафедри історії України Дрогобицького державного педагогічного університету імені Івана Франка (Україна, Дрогобич) vilnickiy@gmail.com

Наталія КАНТОР, старший викладач кафедри правознавства, соиіології та політології Дрогобицького державного педагогічного університету імені Івана Франка (Украӥна, Дрогобич) natali.kantor@gmail.com

\section{РЕПРЕСІЇ РАДЯНСЬКОЇ АДМІНІСТРАЦІЇ ПРОТИ РОДИН ПОВСТАНЦІВ У КАРПАТСЬКОМУ КРАЇ ОУН (1945 - 1954)}

\footnotetext{
У статті вперше на основі невідомих та маловідомих документів досліджується проблема використання сімей націоналістів в агентурних комбіначіях. Виокремлюються основні напрямки цієї політики репресивно-каральних органів. Автор довів, щчо чей напрям діяльності спецорганів відігравав надзвичайно важливу роль.

Ключові слова: Карпатський край ОУН, визвольний рух, націоналісти, родини, репресивнокаральні органи.
}

The statement of the problem. It is difficult enough to describe in words the tragic situation in which Western Ukraine's population found itself in the 1940s - 1950s. The antago-

\footnotetext{
${ }^{1}$ Публікація містить результати досліджень, проведених при грантовій підтримці Державного фонду фундаментальних досліджень за конкурсним проектом Ф77/80 - 2018 (договір від 29.03.2018)
} 
nism in the society which the Soviet administration tried in all possible ways to ignite during that period eventually reached its peak. Not only the direct participants of the liberation movement and its sympathizer, but also their families became the victims of cruel repressions. The scales of reprisals of the Soviet administration against families of nationalists are literally unimaginable.

The analysis of researches. Whereas the deportation policy has already been reflected in a number of works, the problem of the use by repressive bodies of families of insurgents as hostages, and recruitments of their relatives for the control over the underground is practically not elucidated. This question has been sporadically studied by such researchers as I. Bilas, D. Vedeneyev and H. Bystrukhin, A. Kentiy, Y. Kyrychuk, and A. Rusnachenko in generalising works on the history of the Ukrainian liberation movement (Bilas, 1994; Vedeneyev, Bystrukhin, 2007; Kentiy, 1999a; Kentiy, 1999b; Kyrychuk, 2003; Rusnachenko, 2002). V. Serhiychuk was the first to publish a fundamental documentary base for the study of the question of reprisals against members of families of OUN and UPA fighters (Roman Shukhevych, 2007a; Roman Shukhevych, 2007b; Serhiychuk, 2006; Serhiychuk, 2005). Deportation, that most widespread form of the repressive policy of the Soviet administration has found expression in Y. Nadolskyi's investigation (Nadolskyi, 2008), in which the author analyzes the reasons, methods and stages of carrying out of deportations. T. Vrons'ka compiled a serious theoretical-methodological and archeographical work devoted to reprisals against families of insurgents (Vrons'ka, 2009). However, a complex research of the Soviet administration's repressive policy against families of nationalists in the Carpathian area (alias Karpatskyi Krai) of the OUN is still absent.

The article's purpose is - on the basis of unknown documents and materials to shed more light on the repressive policy against families of the Ukrainian nationalists as one of forms of struggle of the retaliatory system against movements for Ukrainian independence. At the same time, the author intentionally pays little attention to deportation campaigns as they make up a separate matter which deserves special research.

The statement of the basic material. The love and support of the near and dear ones in difficult conditions of the underground were - and have always been - of enormous moral and psychological value, ant the leaders of the underground well understood that. Sharing common views, the wives of insurgents sacrified all they could in order not only to support their husbands and be near them, but also to conduct the struggle together with them. As a matter of fact, it is necessary to underline, that families were the most sensitive point of the nationalists. The special organs well understood that and effectively used that.

Almost all the commanders of regional, district, and county leaderships were married men (BSA SSU (the Branch State Archive of the Security Service of Ukraine). File 2. Description 59 (1953). Case 5. Vol. 4. Page 142; D. 34 (1960). C. 18. P. 72-73). In somewhat lesser degree the managerial personnel of regional and sectional leadership married. That situation, first of all, is explained that they were of considerably younger age in comparison with the former. It is necessary to notice, that in the underground a marriage took place with the permission of the leadership members. In particular, V. Livyi, a security service responsible of Karpatskyi Krai regional leadership of OUN informed the leader of this area V. Sydor-«Shelest» on August 19th, 1948, that OUN's security service responsible in Drohobych district Vasyl Shevaniuk-«Zaliznyi» («Iron-made») had asked of the permission to marry Natalia Posatska-«Uliana» and received such a permission (BSA SSU. F. 2. D. 98 (1954). C. 8. P. 83). Such situations were caused by difficult conditions of struggle and possibilities of influencing underground members through families. 
In most cases wives of underground members, especially, of their leaders, worked sideby-side with them, like, for example, typists, combating with them and, unfortunately, perishing together with their husbands. For instance, like Mykola Tverdokhlib-«Hrim» («Thunder») with his wife Olha Herasymovych (both lost their lives on 5 May 1954), or Volodymyr Livyi-«Jordan» and his wife Dariya Tsymbalist-«Olia» (perished on 12 April 1948, in the village of Topilske of Rozhniativ district), like Ivan Lavriv-«Nechai» together with Halyna Moroka-«Of the steppe», the Ukrainian Red Cross (further on referred to as URC) responsible Nadvirna county leadership of OUN Mariya Mytsko-«Mariya» in the underground married «Kolia», Mykola Korzhenivskyi, deputy responsible of SS of Bukovyna district leadership of OUN, and the SS' responsible person in Drohobych regional leadership of OUN Vasyl' Medvid-«Vasylchenko» was married to Vasyl' Kuk-«Lemish» sister (BSA SSU. F. 5. C. 67448. V. 1. P. 37. P. 37; F. 2. D. 56 (1953). C. 6., V. 5., P. 112; D. 60 (1953). C. 14. P. 245-246; D. 93 (1954). C. 2. P. 45; D. 110 (1954). C. 2. V. 5. P. 135; F. 13. C. 372. V. 95. P. 164-165; F. 65. C. 9112. V. 2. P. 145). The responsible for propagation of Karpatskyi Krai regional leadership of the OUN Mykhailo Diachenko was married to Maria Savchuk (in 1942 their son Sviatoslav was born) (Kohut, 2002: 20-21).

The majority of the administrative board got married during the German occupation. The nationalists often married in the conditions of the underground.

The repressive-retaliatory bodies mainly carried out their influence on the underground members through their families. For this purpose, first of all, arrests, recruitments, blackmails, hostage taking, and deportations of whole families were carried out. In particular, the Cheka agents, having learnt that the SS responsible «Cossack» of Kolomyia district leadership of the OUN had married one Nadiya, they - on condition of no possibility of catching «Cossack» but began searching for his wife. During a searching operation on July 28th, 1951 she was captured wounded. During the interrogation «Nadia» had to confess that she and «Cossack» had a son, whose name was Stepan and who lived with her parents. Further on, the investigators learnt that «Cossack» loved his wife and son very much and for their sake was ready to fulfil any possible requirements, even to begin all sorts of cooperation. Having checked up this information, the Cheka agents captured «Cossack's» security bodyguards of and by means of correspondence convinced him to the cooperation with them. In «Cossack's» first letter to the special agencies the depth of his feelings is felt, which tore his heart apart and because of which he turned to such extreme actions: «I answer the raised question... What concerns Nadia, I may agree that there are drawbacks with her, but let's do all that all would be al right. It is enough for me that she is alive and recovering. Of course, you can organize a meeting with the parents, but not for the sake of convincing me, but in order that Nadia could console them. I am very sorry for them, for me they are the next after Stepanko.... I wish our personal meeting happened as quick as possible, so that everything could have been fixed, including the discussion of the communication plan, code numbers, and protection signs» (BSA SSU. F. 13. C. 372. V. 56. P. $185-187$; F. 2. D. 28 (1960). C. 18. P. 200).

The policy of the Soviet power concerning nationalists was a terrorist one, as to families of insurgents not only reprisals were implemented, but they also used them as banal hostages. The Cheka agents tried to play on holy parental feelings. So, while carrying out the search of Mykola Tverdohlib-«Hrim», the Chekists determined that in 1948 his wife Olha Herasymovych, having passed to an illegal position, had left her son Yarema in the care of her sister Ivanna Herasymovych. In August, 1949, for her links with the underground, Ivanna Herasymovych was exiled in Khabarovsk region, whereas «Hrim's» son was placed in a 
children's home in Rohatyn wherein he lived and studied in the first grade under the name Yakiv Oleksandrovych Dyhin. M. Tverdokhlib asked Anna Dmytriv to kidnep his son. The Cheka agent wanted to use «Hrim's» and Olha Herasymovych' parental feelings to their son and to carry out actions (simultaneously promising to him of the preservation of his son's life and return) which would make «Hrim» to cooperation with the organs of the Ministry of Internal Affairs. With that end in view the investigators photographed his son in different foreshortenings, and then - with the help of the teacher - wrote a letter (forging his son's handwriting) to the father and mother, passing it to «Hrim» together with the photos (BSA SSU. F. 2. D. 19 (1959). C. 6. P. 6).

As the majority of the managerial cadres in Karpatskyi Krai were married and had children, they tried to secure them as much as possible against possible reprisals, and in the future - against the use of them by the repressive organs for an influence on their parents. An awful tragedy happened to Bohdan Yatskiv-«Safron» alias «Denys», the assistant of the responsible of the OUN SS member of the Karpatskyi Krai regional leadership. In May 1949 his wife was killed during a special operation, and the Soviet bodies allocated his 4 year old son into a children's home in Stanislaviv. The Chekists - for the purpose of capturing «Safron» - tried to make use of his ten year old daughter who was hiding in Lviv in her uncle Dmytro's dwelling. However, despite his great love of children, they could not make Bohdan Yatskiv to agree to a cooperation with them (BSA SSU. F. 2. D. 110 (1954). C. 2. V. 5. P. 367-370).

The Chekists were also chasing the wife of the last leader of Bukovyna county Yulian Matviyiv-«Nedobytyi». In the night from the 2nd to the 3rd of February, 1951 his wife - Liubov Mykhailivna Matviyiv-Dytsio-Kubranovych (b. 1911 in the town of Kuty, Stanislaviv region) was arrested in the town of Stryi. At the interrogation she told nothing, therefore the Chekists decided to «elaborate» her by help of the internal agents. After a chain of attempts, it became clear that she had married Y. Matviyiv yet in 1939. Then, for conspiracy reasons in view of the repressive organs, she announced her fictitious marriage with a Pole, Ditsio. After the re-conspiration L. Matviyiv was necessitated to move to the town of Stryi. With Yulian she had children, of whose health the father constantly showed his interested in letters. In November of 1950 «Nedobytyi» gave 2 thousand roubles to his wife through mediators. After his arrest the Cheka agents wanted - through the forced influence of his wife - to make Yulian Matviyiv to confess his guilt. However, that brought about no results (BSA SSU. F. 2. D. 34 (1960). C. 15. P. 38-39; D. 59 (1953). C. 5. V. 6. P. 239; D. 98 (1954). C. 5 . V. 1. P. 24-26; T. 2. P. 175-177; D. 99 (1954). C. 15. P. 62-81).

A practice of the Soviet bodies to find out and through the relatives to enlist the insurgents into their case or make them confess their guilt lasted for long. In all complex inquiries concerning the secret agents' cases on administrative boards of some or other leadership, all their relation links, places of residence, and the agents directed to the «elaboration» of the latter were fully described, the relatives who had already suffered reprisals were notified, as well as possible secret-service combinations concerning those who had necessarily be subjected to repressions (BSA SSU. F. 2-H. D. 60. C. 16. P. 2-7, 319-320; D. 99. C. 2. V. 3. P. 263-265). The Cheka agents, knowing the vulnerable points of underground activists, i. e., their families and relations, constantly conducted searches.

The families of nationalists were sieged by agents from their nearest environment which could not even be suspected in the cooperation with the Soviet power (BSA SSU. F. 71. D. 6. C. 387. V. 1. P. 175-176). The Cheka agents were not particularly selective in methods 
applied to an influence on underground workers. Members of OUN and commanders of UPA were but usual people who loved, married, had children, and wanted to live in the independent Ukrainian state.

Throughout 1945 - 1950s the Cheka agents actively arrested the relatives of underground members whom they tried to use for their special purposes. The fates of relatives and even of the children of the killed leaders were rather tragic. As a rule, those were adopted by the families of the Soviet administration workers or the security officers. On 29 April 1956 Yevheniya Andrusiak had been released from imprisonment and she began searching for her son. After titanic efforts, she managed to find out that her son was adopted by a family of the KGB officer Korsakov. The latter, after moving from Stanislaviv, lived in the town of Yeln in Smolensk region (Russia) (Kohut, 2001: 33).

Almost each underground worker had to risk not only his own life and health, but also the life and health of his relatives. The Cheka agents carefully worked over revealing not only the wives and children, but also the parents and close relatives of the leaders of the underground of Karpatskyi Krai of OUN. The parents and relatives of almost all underground leaders were subjected to repressions in different ways. In particular, the Cheka agents yet in 1941 found the father of the chief of Karpatskyi Krai regional leadership of the OUN Mykola Melnyk (b. 1891, in the village of Berehznytsia) who worked as a deacon. Before he should be moved out, he was transferred into an illegal position, and during the German occupation he worked as the head of a rural government. With the arrival of the Bolsheviks he passed to an illegal position. The mother of «Robert», Melnyk Ustyna Andriyivna (b. 1893, the resident of the village of Berezhnytsia), in May, 1941 was sent into exile in the remote areas of the USSR (BSA SSU. F. 2-H. D. 55 (1953). C. 6. V. 1. P. 399, 401). Already after the German-Soviet war in the village of Berezhnytsia four uncle of Ya. Melnyk were found out: Andriy Melnyk (a smith), Yuriy Melnyk (an office worker of the local village Soviet), Dmytro Melnyk and Petro Melnyk (farmers) (BSA SSU. F. 2-H. D. 55 (1953). C. 6. V. 1. P. 399-401). In 1949 the Cheka agents carried out an active search for Ya. Melnyk's sister, Volodymyra Mykolayivna Melnyk who in February 1948 fled from a special detention settlement and illegally lived in the village of Broshniv. Furthermore, after all the tests which that woman had to suffer, she did not changed her outlook. Having arrived at the village of Berezhnytsia she began a vigorous activity in support of the underground, gathering combat intelligence information, delivering foodstuff, etc. (BSA SSU. F. 2-H. D. 98 (1954). C. 1. V. 2. P. 30-31).

Many members of families of underground workers could not stand severe realities of everyday life and ended in giving up their underground work, so to say, coming with cap in hand. However, such give-ups were caused by the objective reasons. So, operational agents of MMSS (Management of Ministry of State Security) of Chernivtsi region on April 2nd, 1949 forced Mykola Dmytriuk-«Quick» alias «Ruban», the commander of Sadhirya district leadership of the OUN, to legalize. However, it was preceded by an arrest and sentence of his father Vasyl Dmytriuk. Eventually, the father had appeared a hostage, and after his son's confession of his guilt, V. Dmytriuk was released (BSA SSU. F. 2-H. D. 60 (1953). C. 4. V. 2. P. 240-242; F. 13. C. 372. V. 86. P. 121-122). Special agents intentionally made use of strong filial and parental feelings of the underground workers which allowed them to manipulate the latter.

Attempts of enlisting of family members and distant relatives and through them to influence the underground made up an important direction of the repressive policy of the Soviet power. However, such an activity in very many cases was ineffectual. Not many people gave in to recruitment. 
Usually, those on whom pressure was made, changed their position into the illegal one. So, in January of 1950 Victoria Valihura, the wife of S. Khodok-«Spartak», the responsible of the SS of Drohobych county leadership of OUN, came to the 2nd police station of Drohobych to confess her guilt. Prior to 1947 V. Valihura had lived legally in Drohobych together with her mother, and after an attempt to enlist her she immediately passed to an illegal position. By the way, after the underground had learnt about that, it forbade «Spartak» to meet with the wife. However, the her husband ignored the prohibition. The chekists considered two variants of the succession of events. The first, - due to the close common ties of «Spartak» and Valihura, the possibility of their secret meetings was absolutely real. The second implied that all the materials and facts should be use for the sake of compromising of «Spartak» (BSA SSU. F. 2-H. D. 60. C. 16. P. 288-290).

It was through an active operational work of special agents the underground's leadership did not approve of insurgents' meetings with their families and relatives who lived legally.

In was a particularly hard time for the wives of the underground leaders, because their wives frequently became objects of repressive measures. Here again not only arrests, recruitment, or blackmail of the health and life of children took place, but the percent of destruction of wives of the underground members was high.

Not seldom the whole families worked in the underground and, unfortunately, together they also perished. There were cases with the underground activists that matrimonial member had to suffer the pain of the loss of his or her dear, beloved, or close ones.

Actually, almost each nationalist had to endure a personal tragedy. Someone's relatives were evicted into the remote areas of the Soviet Union, some others' relatives perished, cases of destruction of the underground leaders together with their wives were widespread.

The destruction of children of underground workers, without doubt, was the greatest tragedy. For the parents of West Ukrainian region in he 1940s - 1950s losses of their children became an almost usual event. During a special operation on 25 December, 1950 Zenoviy-Peter-«Bohdan» was killed (b. 1930, the security guard of a technical link of Stanislaviv district leadership of OUN): he was the son of Kostiantyn Peter, the head of this structure (BSA SSU. F. 2-H. D. 60 (1953). C. 3. V. 5. P. 194).

In the end of the 1940s - beginning of the 1950s deported families of nationalists started returning from their exile. Having arrived back to their native places, members of families started restoring their former links with the underground. Among nationalists they enjoyed great trust, and - in their turn - their families gave a considerable aid to the underground. In other words, neither terror, nor reprisals, humiliation, and physical tortures could break and «re-educate» the people. For example, in the beginning of 1946 the family (father, mother, and brother) of Hryhoriy Sokolyk-«Zymnyi», head of Sambir county leadership of OUN, came back in the village of Bereznyzia. from exile, which had been sent out in $1940-1941$. Yuliya Hanushchak's family (mother and sister) also returned from exile. In even larger scales families of ordinary underground members came back and at once started working on in the underground. That is to say, that despite all miseries, troubles, losses of family members and relations, the Soviet power was no success in suppressing and breaking of the patriotic feelings (BSA SSU. F. 71. D. 6. C. 105. P. 154-155). That all effected in a desperate act of V. Maistruk, the chief of MMSS of Drohobych region, who addressed a suggestion of prohibiting returns of families of the exiled nationalists to the ministry.

The conclusions. The family and a circle of relations are the greatest values which each person has. In its struggle against the underground, the repressive system, using all possible mean methods, fought with the Ukrainian liberation movement even by means of reprisals 
against their families, its agencies used even the near and dear ones in their operational combinations. The majority of these actions contradicted the international conventions and moral-ethical bases. In other words, the Soviet power combated not only direct participants of the liberation movement, but also their families. In fact, the official power at the state level carried out terrorist policy. Such actions of the administration in a still greater extent ignited the local population's anger. Studies of the other forms of struggle against insurgents in the Carpathian area alias Karpatskyi Krai of the OUN form a perspective direction of research.

\section{BIBLIOGRAPHY}

Білас, 1994 - Білас I. Репресивно-каральна система в Україні 1917 - 1953. Суспільно-політичний та історико-правовий аналіз. У двох книгах. Книга перша. К.: Либідь; Військо України, 1994. $432 \mathrm{c}$

Вєдєнєєв, Биструхін, 2007 - Вєдєнєєв Д., Биструхін Г. Двобій без компромісів. Протиборство спецпідрозділів ОУН та радянських сил спецоперацій. 1945 - 1980-ті роки: Монографія. К.: K.I.C., 2007. 568 c.

Вронська, 2009 - Вронська Т. Заручники тоталітарного режиму: репресії проти родин «ворогів народу» в Україні (1917 - 1953 рр.). К.: Інститут історії України, 2009. 486 с.

ГДА СБУ - Галузевий державний архів Служби безпеки України.

Кентій, 1999а - Кентій А. Нарис боротьби ОУН-УПА в Україні (1946 - 1956 рр.). К.: Інститут історії України НАН України, 1999. 111 с.

Кентій, 1999b - Кентій А. Українська повстанська армія в 1944 - 1945 рр.. К.: Інститут історії України НАН України, 1999. 220 с.

Киричук, 2003 - Киричук Ю. Український національний рух 40-50-х років XX століття: ідеологія та практика. Львів: Добра справа, 2003. 464 с.

Когут, 2002 - Когут М. Герої не вмирають... Кн. 2. Калуш: «Артекс», 2002. 72 с.

Когут, 2001a - Когут М. Командир Різун. Дрогобич: Видавнича фірма «Відродження», 2001. 38 с.

Когут, $2001 \mathrm{~b}$ - Когут М. Герої не вмирають... Кн. 1. Дрогобич: Видавнича фірма «Відродження», 2001. 62 с.

Літопис УПА, 1995 - Літопис УПА. Т. 28: Марія Савчин: Тисяча доріг. (Спомини). Торонто - Львів: Видавництво Літопис УПА, 1995. 598 с.

Надольський Й. Е. Депортаційна політика сталінського тоталітарного режиму в західних областях України (1939 - 1953 рр.). Луцьк: РВВ «Вежа» Волин. нац. ун-ту ім. Лесі Українки, 2008. 260 с.

Роман Шухевич, 2007a - Роман Шухевич у документах радянських органів державної безпеки $(1940$ - 1950). К.: ПП Сергійчук М. І., 2007. Т. 1. 640 с.

Роман Шухевич, $2007 \mathrm{~b}$ - Роман Шухевич у документах радянських органів державної безпеки $(1940$ - 1950). К.: ПП Сергійчук М. І., 2007. Т. 2. 584 с.

Русначенко, 2002 - Русначенко А. Народ збурений: Національно-визвольний рух в Україні й національні рухи опору в Білорусії, Литві, Латвії, Естонії у 1940 - 50-х роках / Анатолій Русначенко. К.: Університетське видавництво «Пульсари», 2002. 519 с.

Сергійчук, 2006 - Сергійчук В. Тавруючи визвольний прапор. Діяльність агентури та спецбоївок НКВС-НКДБ під виглядом ОУН-УПА. Видання друге, доповнене. К.: ПП Сергійчук М.І., 2006. $184 \mathrm{c.}$

Сергійчук, 2005 - Сергійчук В. Український здвиг: Прикарпаття. 1939 - 1955 рр. К.: Українська Видавнича Спілка, 2005. 840 с.

Стародубець, 2006 - Стародубець Г. Українське повстанське запілля (друга пол. 1943 - поч. 1946 років). Тернопіль: Підручники і посібники, 2006. 527 с.

\section{REFERENCES}

Bilas, 1994 - Bilas I. Represyvno-karalna systema v Ukraini 1917 - 1953 [The repressive system in Ukraine in 1917 - 1953]. Suspilno-politychnyi ta istoryko-pravovyi analiz. U dvokh knyhakh. K.: Lybid; Viisko Ukrainy, 1994. Kn. 1. 432 p. [in Ukrainian] 
Viedienieiev, Bystrukhin, 2007 - Viedienieiev D., Bystrukhin H. Dvobii bez kompromisiv. Protyborstvo spetspidrozdiliv OUN ta radianskykh syl spetsoperatsii [An Uncompromising Combat. The Opposition of Special Subdivisions of OUN with Soviet Special Operations Forces]. 1945 - 1980ti roky. Kyev: K.I.S., 2007. 568 p. [in Ukrainian]

Vronska, 2009 - Vronska T. Zaruchnyky totalitarnoho rezhymu: represii proty rodyn «vorohiv narodu» v Ukraini (1917 - 1953 pp.) [Hostages of the totalitarian regime: reprisals against families of «enemies of the people» in Ukraine (1917 - 1953)]. K.: Instytut istorii Ukrainy, 2009. 486 p.

HDA SBU - Haluzevyi derzhavnyi arkhiv Sluzhby bezpeky Ukrainy [Sectoral State Archive of Security Service of Ukraine]. [in Ukrainian].

Kentii, 1999a - Kentii A. Narys borotby OUN-UPA v Ukraini (1946 - 1956 rr.) [On functioning of UPA departments in Chernivtsi land; An outline of the struggle of OUN-UPA in Ukraine (1946 1956)]. Kyiv, Instytut istorii Ukrainy NAN Ukrainy, 1999. 111 p. [in Ukrainian]

Kentii, 1999b - Kentii A. V. Ukrainska povstanska armiia v $1944-1945$ rr. [Ukrainian Insurgent Army in 1944 - 1945] Kyiv: Instytut istorii Ukrainy NAN Ukrainy, 1999. 220 p. [in Ukrainian]

Kyrychuk, 2003 - Kyrychuk Yu. Ukrainskyi natsionalnyi rukh 40-50-kh rokiv XX stolittia: ideolohiia ta praktyka [Ukrainian Nationalist Movement of 1940s-1950s: Ideology and Practice]. Lviv, Dobra sprava, 2003. 464 p. [in Ukrainian]

Kohut, 2001a - Kohut M. Heroi ne vmyraiut... [Heroes Do Not Die] Kn. 1. Drohobych: Vidrodzhennia, 2001. 62 p. [in Ukrainian].

Kohut, 2001b - Kohut M. Komandyr Rizun [Commander Rizun]. Drohobych: Vydavnycha firma «Vidrodzhennia», 2001.38 p.

Kohut, 2002 - Kohut M. Heroi ne vmyraiut... [Heroes Do Not Die] Kn. 2. Kalush: Arteks, 2002. 72 p. [in Ukrainian].

Litopys UPA, 1995 - Litopys UPA. T. 28: Mariia Savchyn: Tysiacha dorih. (Spomyny) [Mariya Savchyn: a thousand of ways. (Recollections)]. Toronto - Lviv: Vydavnytstvo Litopys UPA, 1995. 598 p.

Nadolskyi Y. E. Deportatsiina polityka stalinskoho totalitarnoho rezhymu v zakhidnykh oblastiakh Ukrainy (1939 - $1953 \mathrm{rr}$.) [Deportatsion policy of Stalin totalitarian regime in western areas of Ukraine (1939 - 1953)]. Lutsk: RVV «Vezha» Volyn. nats. un-tu im. Lesi Ukrainky, 2008. 260 p.

Roman Shukhevych, 2007a - Roman Shukhevych u dokumentakh radianskykh orhaniv derzhavnoi bezpeky $(1940-1950)$ [Roman Shukhevych in documents of the Soviet agencies of state security $(1940$ - 1950)]. K.: PP Serhiichuk M. I., 2007. T. 1. 640 p.

Roman Shukhevych, 2007b - Roman Shukhevych u dokumentakh radianskykh orhaniv derzhavnoi bezpeky $(1940$ - 1950) [Roman Shukhevych in documents of the Soviet agencies of state security $(1940$ - 1950)]. K.: PP Serhiichuk M. I., 2007. T. 2. 584 p.

Rusnachenko, 2002 - Rusnachenko A. Narod zburenyi: Natsionalno-vyzvolnyi rukh v Ukraini y natsionalni rukhy oporu v Bilorusii, Lytvi, Latvii, Estonii u 1940 - 50-kh rokakh [The Revolted People: National liberation movement in Ukraine and national resistance movements in Belarus', Lithuania, Latvia, and Estonia in the 1940s - 1950s]. Kyiv, Universytetske vydavnytstvo «Pulsary», 2002. 519 p. [in Ukrainian]

Serhiichuk, 2006 - Serhiichuk V. Tavruiuchy vyzvolnyi prapor. Diialnist ahentury ta spetsboivok NKVS-NKDB pid vyhliadom OUN-UPA [Blaspheming the flag of liberation. The activity of agencies and special groups of NKVS-NKGB under the image of OUN-UPA]. Vydannia druhe, dopovnene. K.: PP Serhiichuk M.I., 2006. 184 p.

Serhiichuk, 2005 - Serhiichuk V. Ukrainskyi zdvyh: Prykarpattia [the Ukrainian revolt: SubCarpathia]. 1939 - 1955 rr. K.: Ukrainska Vydavnycha Spilka, 2005. 840 p. [in Ukrainian]

Starodubets, 2006 - Starodubets H. Ukrainske povstanske zapillia (druha pol. 1943 - poch. 1946 rokiv) [Ukrainian insurgent underground (the second half of 1943 - beginning of 1946)]. Ternopil: Pidruchnyky i posibnyky, 2006. 527 p.

Стаття надійшла до редакиіï 8.04.2018 p. 